\title{
Sistem Pendukung Keputusan Pemilihan Subkontrak Menggunakan Metode Entropy dan TOPSIS
}

\author{
Jamila dan S. Hartati
}

\begin{abstract}
Outsourcing is a part of production process of manufacturing industry which contribute for suitainability of a manufacture process. Choosing appropriate subcontractor which match spesification is not easy. In order to help company in determining credible subcontractors is needed a decision support system.

Selection of decision support system for the production of subcontracting gloves uses Entropy and TOPSIS methods. Entropy method is used to give weight to the criteria. TOPSIS (Technique for Order Preference by Similarity to Ideal Solution) method is used to select the best subcontractors, where subcontracting was elected not only has the shortest distance from the positive ideal solution but it also has the longest distance from the negative ideal solution. Designing of systems use ERD and DFD for identifying the needs of users and systems, and as for guiding the software implementation.

The results of this research are the establishment of an application used to select subcontractors based on established criteria. Test results on the application can provide decision input/suggestion, although the criteria used in making decision is different. Subcontract selection decision support system can be an alternative to choose subcontractors for the production of gloves in PT. Adi Satria Abadi Yogyakarta.
\end{abstract}

Keywords-DSS, Decision Support System, Entropy, TOPSIS, Subcontract

\section{Pendahuluan}

$\mathrm{P}$ ada proses produksi di bidang manufaktur, subkontrak merupakan salah satu bagian yang ikut berperan terhadap kelangsungan suatu pabrik. Penggunaan subkontrak juga akan menurunkan biaya produksi jika dibandingkan perusahaan tetap memaksakan memproduksi sendiri dengan melakukan jam kerja lembur. Sudah selayaknya manajemen perusahaan selalu mempertimbangkan kapasitas normal yang tersedia [1].

Jamila, staf pengajar, Akademi Teknnologi Kulit, Yogyakarta, Indonesia 55188

Sri Hartati, Departemen Ilmu Komputer dan Elektronika, Fakultas Matematika \& Ilmu Pengetahuan Alam, UGM, Yogyakarta, Sekip Utara PO BOX BLS.21 Yogyakarta 55281, e-mail : shartati@ugm.ac.id
Pola subkontraktor adalah suatu sistem yang menggambarkan hubungan antara usaha besar dengan usaha kecil atau menengah [2].

Kegiatan subkontrak yang dijalankan secara makro efisiensi nasional dan secara mikro efisiensi perusahaan akan memperkuat struktur ekonomi nasional dan mewujudkan demokrasi ekonomi [3].

Keputusan untuk memilih subkontrak yang sesuai dan menghasilkan produk yang berkualitas dengan waktu yang tepat bukan pekerjaan yang mudah.Kesalahan dalam pemilihan subkontrak dapat menimbulkan kerugian bagi perusahaan misalnya menyebabkan kualitas produk menurun, jadwal pengiriman terganggu, biaya produksi semakin meningkat dan hal yang terpenting hilangnya kepercayaan pelanggan.

Selama ini perusahaan menggunakan kriteria utama dalam pemilihan subkontrak hanya berdasarkan pada kualitas sampel sarung tangan yang dihasilkan oleh subkontrak. Ketepatan waktu pengiriman, service atau pelayanan terutama jika terjada masalah pada saat maupun setelah proses produksi dan penilaian hasil pengecekan kondisi di lapangan (survey ke lokasi subkontrak) tidak dihitung secara pasti, melainkan hanya berdasarkan perkiraan. Akibatnya seringkali kemampuan dari subkontrak tidak seperti yang diharapkan oleh perusahaan.

Pengambilan keputusan adalah suatu proses memilih diantara berbagai alternatif [4], pengambilan keputusan manajerial sinonim dengan proses keseluruhan dari manajemen [5]. Sistem pendukung keputusan (Decision Support System/DSS) adalah sistem pendukung keputusan bagi para pengambil keputusan manajemen yang menangani masalah-masalah tidak terstruktur dan bertujuan mendukung penilaian manajer bukan mencoba menggantikannya [4,6]. Sistem pendukung keputusan tidak ditekankan untuk membuat keputusan dengan sekumpulan kemampuan untuk mengolah informasi atau data yang diperlukan dalam proses pengambilan keputusan tetapi sistem hanya berfungsi sebagai alat bantu manajemen. Sistem tidak dimaksudkan untuk menggantikan fungsi pengambil keputusan dalam membuat keputusan, tetapi sistem 
dirancang untuk membantu pengambil keputusan dalam melaksanakan tugasnya.

Penelitian yang sudah pernah dilakukan terkait dengan masalah subkontrak, pengambilan keputusan dan metode yang digunakan diantaranya adalah penggunaan metode Analytical Hierarchy Process (AHP) untuk menghitung bobot dari masing-masing kriteria dan indikator kinerja supplier sehingga pada akhirnya dapat digunakan untuk menyeleksi dan mengevaluasi supplier sehingga dapat diketahui supplier yang terpilih [7]. Evaluasi pusat distribusi (situasi iklim, jumlah permintaan, kemungkinan pengembangan, biaya investasi, kualitas performance laboratorium dan ketersediaan transportasi) digunakan sebagai kriteria untuk mendapatkan alternatif terbaik dari 3 alternatif yang diusulkan menggunakan Fuzzy Multi Criteria Decision Making (FMCDM) [8]. Pemilihan supplier untuk industri makanan dengan menggunakan metode entropy dan perangkingan suplier dengan menggunakan metode promethee [9]. Pengukuran peringkat yang mampu mengembangkan diagnosis industri real estate serta memberikan informasi konstruktif bagi pemerintah untuk mengarahkan reformasi makro di bidang industri real estate di China. Dilakukan evaluasi dan seleksi proyek sebelum diputuskan untuk memilih invenstasi yang tepat dengan menggunakan metode PCA (Principal Component Analysis) dan TOPSIS sebagai metode perangkingan [10]. Pemilihan alternatif terbaik dari Net Present Value, Rate of Return, Benefit Cost Analysis dan Payback Period digunakan sebagai pilihan untuk investasi yang tepat menggunakan Fuzzy TOPSIS [11]. Pemilihan mahasiswa terbaik untuk mendapatkan beasiswa dari 8 jenis beasiswa yang ditawarkan kepada mahasiswa menggunakan metode Analytical Hierarchy Process (AHP). AHP digunakan sebagai model untuk menentukan tingkat kepentingan (bobot) pada setiap kriteria dan subkriteria [12].

\section{Metode Penelitian}

Sistem pendukung keputusan untuk pemilihan subkontrak bertujuan untuk mencari alternatif terbaik berdasarkan kriteria-kriteria yang ditetapkan oleh perusahaan. Alternatif yang dimaksud adalah perusahaan yang menjadi subkontrak untuk memproduksi sarung tangan sesuai dengan pesanan, sedangkan kriteria adalah karakteristik komponen yang digunakan untuk menilai sekumpulan alternatif (subkontrak).
Bobot kepentingan yang diberikan pada setiap kriteria dapat menggunakan 3 pendekatan yaitu pendekatan subyektif dan pendekatan obyektif. Pendekatan subyektif adalah bobot kepentingan pada setiap kriteria diserahkan sepenuhnya pada pengambil keputusan (DM), sedangkan pendekatan obyektif adalah bobot kepentingan pada setiap kriteria diserahkan sepenuhnya kepada sistem. Pendekatan yang ketiga adalah pendekatan subyektif-obyektif yaitu bobot kepentingan pada setiap kriteria dihitung berdasarkan hasil bobot dari pendekatan subyektif dan pendekatan obyektif. Melalui pendekatan subyektif dan obyektif maka dapat dihasilkan bobot kriteria berdasarkan karakteristik data sekaligus dapat mengakomodasi preferensi subyektif dari pengambil keputusan.

Proses pemilihan subkontrak dapat menggunakan kriteria penilaian yang diinginkan oleh pihak perusahaan. Bobot kepentingan terhadap kriteria juga dapat diberikan berdasarkan preferensi subyektif dari pengambil keputusan. Berbagai metode dapat digunakan untuk memodelkan bobot kriteria, salah satu metode pembobotan kriteria adalah metode entropy. Metode entropy dapat menghitung bobot berdasarkan karakteristik data pada kriteria, semakin tinggi variasi antar data pada kriteria maka bobot kriteria tersebut makin tinggi atau semakin penting. Penggunaan metode entropy sangat fleksibel, jika bobot yang dihasilkan dari metode entropy belum dapat digunakan sebagai bobot kriteria untuk pengambilan keputusan maka subyektifitas dari pengambil keputusan dapat diberikan bersama-sama dengan bobot entropy. Hasil penggabungan bobot awal dan bobot entropy akan mengahasilkan bobot kriteria yang sebenarnya. Sedangkan metode yang digunakan untuk mencari alternatif (subkontrak) yang terbaik dapat menggunakan berbagai metode Multi Criteria Decision Making (MADM) diantaranya adalah metode TOPSIS (Technique for Order Prefernce by Similarity to Ideal Solution).

\subsection{Metode Entropy}

Metode entropy dapat digunakan untuk menentukan suatu bobot. Metode entropy dapat menghasilkan kriteria dengan variasi nilai tertinggi akan mendapatkan bobot tertinggi [9]. Langkah-langkah yang digunakan dalam metode entropy adalah sebagai berikut: 


\subsubsection{Membuat matrik rating kinerja}

Matrik rating kinerja adalah nilai alternatif pada setiap kriteria dimana setiap kriteria tidak saling bergantung satu dengan yang lainnya. Matriks keputusan setiap alternatif terhadap setiap kriteria $(\mathrm{X})$, diberikan sebagai:

$\mathrm{X}=\left[\begin{array}{cccc}\mathrm{x}_{11} & \mathrm{x}_{12} & \cdots & \mathrm{x}_{\mathrm{nn}} \\ \mathrm{x}_{21} & \mathrm{x}_{22} & \ldots & \mathrm{x}_{2 \mathrm{n}} \\ \vdots & \vdots & \mathrm{a} & \vdots \\ \mathrm{x}_{\mathrm{n} 1} & \mathrm{x}_{\mathrm{n} 2} & \cdots & \mathrm{x}_{\mathrm{nn}}\end{array}\right]$

dimana:

$\mathrm{i}=1,2, . . \mathrm{n} ; \mathrm{j}=1,2, . . \mathrm{m}$

$\mathrm{x}_{\mathrm{ij}}$ merupakan rating kinerja subkontrak ke-i $(\mathrm{i}=1,2 . ., \mathrm{m})$ terhadap kriteria ke-j $(\mathrm{j}=1,2, . ., \mathrm{n})$.

\subsubsection{Normalisasi tabel data kriteria}

Normalisasi dilakukan dengan terlebih dahulu menentukan nilai paling tinggi (maksimum) dari masing-masing subkontrak pada setiap kriteria. Normalisasi data nilai masing-masing subkontrak $(\mathrm{i}=1,2, . ., \mathrm{m})$ terhadap kriteria $(\mathrm{j}=1,2, \ldots, \mathrm{n})$ diberikan pada persamaan 2 .

$$
\mathrm{d}_{\mathrm{i}}^{\mathrm{j}}=\frac{\mathrm{x}_{\mathrm{i}}^{\mathrm{j}}}{\mathrm{x}_{\mathrm{j} \text { as: }}} \quad \text {; }
$$

dimana:

$$
\begin{aligned}
= & \text { nilai data subkontrak (i) terhadap } \\
& \text { kriteria ( } \mathrm{j} \text { ) yang belum dinormalisasi } \\
\mathrm{x}_{\text {maks }}= & \text { nilai data subkontrak (i) terhadap } \\
& \text { kriteria }(\mathrm{j}) \text { yang belum dinormalisasi } \\
& \text { yang mempunyai nilai paling tinggi } \\
= & \text { nilai data subkontrak (i) terhadap } \\
& \text { kriteria }(\mathrm{j}) \text { yang telah dinormalisasi }
\end{aligned}
$$

selanjutnya nilai masing-masing data yang telah dinormalisasi (persamaam 2) dijumlahkan.

$$
D_{j}=\sum_{j=1}^{n} d_{i}^{j} \quad ; \text { dimana } j=1,2, \ldots, n
$$

dengan $D_{j}$ adalah jumlah nilai data yang telah dinormalisasi pada masing-masing kriteria.

\subsubsection{Perhitungan Entropy}

Perhitungan entropy untuk setiap kriteria ke-j dengan terlebih dahulu menghitung nilai $\mathrm{e}_{\max }$ dan $\mathrm{K}$. Untuk mencari nilai $\mathrm{e}_{\max }$ dan $\mathrm{K}$ diberikan pada persamaan (4) dan (5).

$$
\begin{aligned}
& \mathrm{e}_{\max }=\ln \mathrm{m} ; \mathrm{m} \text { adalah jumlah subkontrak } \\
& \mathrm{K}=\frac{1}{\mathrm{e}_{\max }}
\end{aligned}
$$

Perhitungan entropy untuk setiap kriteria ke-j ditunjukkan pada persamaan (6).

$$
e\left(\mathrm{~d}_{\mathrm{j}}\right)=-\mathrm{K} \sum_{j=1}^{n} \frac{\mathrm{d}_{\mathrm{i}}^{j}}{\mathrm{D}_{j}} \ln \frac{\mathrm{d}_{\mathrm{j}}^{j}}{\mathrm{D}_{\mathrm{j}}}
$$

dimana :

$\mathrm{e}\left(\mathrm{d}_{\mathrm{j}}\right)=$ nilai entropy pada pada masing-masing kriteria $(\mathrm{j}=1,2, \ldots \mathrm{n})$.

A. = nilai data yang telah dinormalisasi.

$\mathrm{D}_{\mathrm{j}} \quad$ = jumlah nilai data yang telah dinormalisasi pada masing-masing kriteria.

setelah mendapatkan e $\left(\mathrm{d}_{\mathrm{j}}\right)$ pada persamaan 6, selanjutnya menghitung total entropy (E) untuk masing-masing kriteria seperti ditunjukkan pada persamaan 7 .

$$
E=\sum_{j=1}^{\mathbb{n}} e(d)
$$

\subsubsection{Perhitungan bobot entropy}

Setelah total entropy sudah dihasilkan dengan merujuk pada persamaan 7 , selanjutnya menghitung bobot pada setiap kriteria dengan menggunakan persamaan 8 dan 9 .

$$
\begin{aligned}
& \bar{z}_{\mathrm{j}}=\frac{1}{\mathrm{n}-\mathrm{E}}\left[1-\mathrm{e}\left(\mathrm{d}_{\mathrm{j}}\right)\right] \quad ; \text { dimana } \mathrm{j}=1,2, \ldots, \mathrm{n} \\
& \sum \overline{\lambda_{\mathrm{j}}}=\operatorname{Sgn}(1)
\end{aligned}
$$

$$
\text { Sign }=+1-
$$

\subsubsection{Perhitungan bobot entropy akhir}

Jika sebelumnya telah ada bobot awal kriteria atau bobot yang telah ditentukan sebelumnya maka hasil bobot entropy akhir untuk tiap kriteria dapat dihitung dengan persamaan 10. Bobot entropy akhir dapat digunakan jika hasil dari bobot entropy tidak sesuai dengan keinginan dari pengambil keputusan.

$$
\lambda_{\mathrm{j}}=\frac{\bar{\lambda}_{\mathrm{j}} *_{\mathrm{j}}}{\sum_{\mathrm{j}=1}^{\mathrm{n}} \bar{\lambda}_{\mathrm{j}} *_{\mathrm{j}} \mathrm{w}_{\mathrm{j}}} \quad ; \text { dimana } \mathrm{j}=1,2, \ldots, \mathrm{n}
$$

dimana:

$\lambda_{\mathrm{j}}=$ bobot entropy akhir,

$\mathrm{n}=$ jumlah kriteria

$\mathrm{w}=$ bobot awal

\subsection{Metode TOPSIS}

TOPSIS (Technique for Order Preference by Similarity to Ideal Solution) adalah salah satu metode yang dapat membantu proses pengambilan keputusan yang optimal untuk menyelesaikan masalah keputusan secara praktis. Hal ini disebabkan konsepnya sederhana dan mudah dipahami, komputasinya efisien dan 
memiliki kemampuan untuk mengukur kinerja relatif dari alternatif-alternatif keputusan dalam bentuk matematis yang sederhana[13]. Langkahlangkah penyelesaiannya adalah sebagai berikut:

\subsubsection{Menentukan matrik rating kinerja}

Matrik rating kinerja adalah nilai alternatif $A_{i}$ $(\mathrm{i}=1,2 . ., \mathrm{m})$ pada setiap kriteria $\mathrm{C}_{\mathrm{j}}(\mathrm{j}=1,2, . ., \mathrm{n})$ dimana setiap kriteria tidak saling bergantung satu dengan yang lainnya. Matriks keputusan setiap alternatif terhadap setiap kriteria (X) terbentuk dengan merujuk pada persamaan 1 .

\subsubsection{Menentukan matrik ternormalisasi}

Metode TOPSIS membutuhkan rating kinerja setiap subkontrak pada setiap kriteria yang ternormalisasi. Untuk membentuk matrik ternormalisasi, digunakan matrik rating kinerja (X) yang terbentuk dari persamaan 1, sedangkan matrik ternormalisasi terbentuk pada persamaan 11 yaitu:

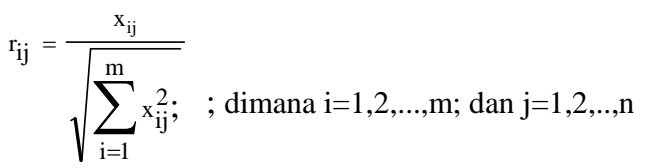

dengan $m$ adalah indeks untuk subkontrak dan $n$ adalah indeks untuk kriteria. Berdasarkan persamaan 11 akan terbentuk matrik ternormalisasi (R) yaitu diberikan pada persamaan 12.

$$
\mathrm{R}=\left[\begin{array}{cccc}
r_{11} & r_{12} & \cdots & r_{1 \mathrm{n}} \\
r_{21} & r_{22} & \cdots & r_{7 \mathrm{n}} \\
\vdots & \vdots & \cdots & \vdots \\
r_{\mathrm{m} 1} & r_{\mathrm{m} 2} & \cdots & r_{\mathrm{mm}}
\end{array}\right]
$$

\subsubsection{Menghitung matrik ternormalisasi terbobot}

Nilai bobot (W) yang menunjukkan tingkat kepentingan relatif setiap kriteria harus diberikan untuk menghitung matrik normalisasi terbobot.

$$
\mathrm{W}=\left\{\mathrm{w}_{1}, \mathrm{w}_{2}, \ldots, \mathrm{w}_{\mathrm{n}}\right\}
$$

Selanjutnya dilakukan perkalian antara bobot pada masing-masing kriteria dengan merupakan rating bobot ternormalisasi $\left(\mathrm{y}_{\mathrm{ij}}\right)$ dimana $\mathrm{i}=1,2, . ., \mathrm{m}$ (subkontrak) dan $\mathrm{j}=1,2, . ., \mathrm{n}$ (kriteria) diberikan pada persamaan 14 .

$$
\mathrm{y}_{\mathrm{ij}}=\mathrm{w}_{\mathrm{j}} \cdot \mathrm{r}_{\mathrm{ij}}
$$

Berdasarkan persamaan 14, maka akan terbentuk matrik keputusan ternormalisasi terbobot Y (persamaan 15).
$\mathrm{Y}=\left[\begin{array}{cccc}w_{1} r_{11} & w_{2} r_{12} & \cdots & w_{n} r_{1 n} \\ w_{1} r_{21} & w_{2} r_{22} & m & w_{n} r_{2 n} \\ \vdots & \vdots & w & \vdots \\ w_{1} r_{m 1} & w_{2} r_{m 2} & \cdots & w_{n} r_{m n}\end{array}\right]$

\subsubsection{Menghitung matriks solusi ideal positif dan} matrik solusi ideal negatif

Nilai solusi ideal positip $\left(\mathrm{A}^{+}\right)$dan nilai solusi negatif $\left(\mathrm{A}^{-}\right)$berdasarkan matrik keputusan ternormalisasi terbobot $Y$ (persamaan 15). Untuk menghitung $\mathrm{A}^{+}$dan $\mathrm{A}^{-}$harus diperhatikan syarat pada persamaan 16 dan persamaan 17 apakah kriteria bersifat keuntungan (benefit) atau kriteria bersifat biaya (cost).

$\mathrm{y}_{\mathrm{j}}^{+}= \begin{cases}\max \left\{\mathrm{y}_{\mathrm{ij}}\right\} & ; \text { dimana } \mathrm{j} \text { adalah kriteria } \\ \mathrm{i} & \text { keuntungan (benefit) } \\ \min \left\{\mathrm{y}_{\mathrm{ij}}\right\} & ; \text { dimana } \mathrm{j} \text { adalah kriteria biaya } \\ \mathrm{i} & (\text { cost })\end{cases}$

$\mathrm{y}_{\mathrm{j}}= \begin{cases}\min \left\{\mathrm{y}_{\mathrm{ij}}\right\} & ; \text { dimana } \mathrm{j} \text { adalah kriteria } \\ \mathrm{i} & \text { keuntungan (benefit) } \\ \max \left\{\mathrm{y}_{\mathrm{ij}}\right\} & ; \text { dimana } \mathrm{j} \text { adalah kriteria } \\ \mathrm{i} & \text { biaya (cost) }\end{cases}$

dengan $\mathrm{i}=1,2, . . \mathrm{m}$ adalah indeks untuk subkontrak dan $\mathrm{j}=1,2, . ., \mathrm{n}$ adalah indeks untuk kriteria.

Berdasarkan persamaan 16 dan 17, selanjutkan dicari nilai solusi ideal positip $\left(\mathrm{A}^{+}\right)$ dan nilai solusi ideal negatif $\left(\mathrm{A}^{-}\right)$dengan menggunakan persamaan 18 dan 19.

$$
\begin{aligned}
& \mathrm{A}^{+}=\left(\mathrm{y}_{1}^{+}, \mathrm{y}_{2}^{+}, \ldots, \mathrm{y}_{\mathrm{n}}^{+}\right) ; \\
& \mathrm{A}^{-}=\left(\mathrm{y}_{1}^{-}, \mathrm{y}_{2}^{-}, \ldots, \mathrm{y}_{\mathrm{n}}^{-}\right) ;
\end{aligned}
$$

dengan $\mathrm{j}=1,2$,..n (n adalah indeks kriteria)

2.2.5. Menghitung jarak antara nilai setiap alternatif dengan solusi ideal positif $\left(D^{+}\right)$dan jarak antara nilai setiap alternatif dengan solusi ideal negatif $\left(D^{-}\right)$

Jarak antara subkontrak dengan solusi ideal positif $\left(\mathrm{A}^{+}\right)$dirumuskan dalam persamaan (20).

$$
D_{i}^{+}=\sqrt{\sum_{j=1}^{n}\left(y_{j}^{+}-y_{i j}\right)^{2}} ; \quad i=1,2, . ., m .
$$

Jarak antara subkontrak dengan solusi ideal negatif dirumuskan dalam persamaan (21.)

$$
D_{i}^{-}=\sqrt{\sum_{j=1}^{n}\left(y_{i j}-y_{j}^{-}\right)^{2}} ; \quad i=1,2, . ., m
$$

2.2.6. Menghitung nilai preferensi untuk setiap subkontrak $\left(V_{i}\right)$.

Nilai preferensi untuk setiap subkontrak diberikan pada persamaan (22). 


$$
\mathrm{V}_{\mathrm{i}}=\frac{\mathrm{D}_{\mathrm{i}}^{-}}{\mathrm{D}_{\mathrm{i}}^{-}+\mathrm{D}_{\mathrm{i}}^{+}} ; \quad \mathrm{i}=1,2, . ., \mathrm{m} .
$$

Nilai $\mathrm{V}_{\mathrm{i}}$ yang lebih besar menunjukkan alternatif yang lebih dipilih.

\subsection{Cara Penelitian}

Berdasarkan hasil observasi, wawancara dan diskusi dengan pihak perusahaan didapat proses pemilihan subkontrak yang terdiri dari beberapa tahap yaitu sebagai berikut:

\subsubsection{Dokumen Penawaran}

Sebelum diusulkan untuk mengikuti seleksi, calon subkontrak menyerahkan dokumen penawaran terlebih dahulu melihat kesesuaian atau spesifikasi calon subkontrak dengan produk yang akan dipesan.

\subsubsection{Pengecekan (survey) di lapangan}

Calon subkontrak yang telah memenuhi spesifikasi yang diinginkan oleh perusahan, selanjutnya akan disurvey atau pengecekan kondisi fisik (bangunan, karyawan, jumlah mesin, kondisi mesin dan lain-lain). Pengecekan dilakukan untuk memastikan kebenaran data yang diberikan oleh masing-msing subkontrak yang akan diseleksi. Hasil pengecekan (survey) diberikan dalam bentuk cek list pada form pengecekan. Perhitungan prosentase hasil dari cek list pada masing-masing subkontrak yang telah disurvey adalah dengan cara membagi hasil nilai ceklist pada setiap subkontrak dengan total nilai. Sedangkan persyaratan nilai minimal yang harus dipenuhi dari hasil survey adalah $80 \%$ dari keseluruhan nilai ceklist. Calon subkontrak yang memenuhi nilai minimal dapat diberikan sampel sarung tangan untuk diproduksi. Jumlah dan spesifikasi sarung tangan yang diproduksi oleh calon subkontrak berdasarkan tipe ukuran sarung tangan yang dipesan. Tipe ukuran (size) sarung tangan (Asia dan Amerika) akan menentukan jumlah sarung tangan yang akan diproduksi[14].

\subsubsection{Hasil produksi sampel sarung tangan}

Calon subkontrak diwajibkan untuk memproduksi sampel sarung tangan yang akan dipesan. Selanjut hasil produksi sampel sarung tangan tersebut diseleksi untuk menilai kualitas produk yang dihasilkan oleh masing-masing calon subkontrak. Penilaian hasil produksi ini akan menentukan calon subkontrak yang terpilih untuk memproduksi sarung tangan. Penilaian hasil produksi merupakan tahap akhir dari keseluruhan proses pemilihan subkontrak dengan kriterian penilaian sebagai berikut:

a. Kualitas, penilaian hasil produksi berdasarkan banyaknya jumlah sarung tangan yang lolos seleksi. Satuan yang digunakan untuk menilai kriteria kualitas adalah persen (\%).

b. Ketepatan waktu, penilaian ketepatan waktu calon subkontrak untuk menyelesaikan produksi sampel sarung tangan berdasarkan tanggal yang telah ditetapkan oleh perusahaan. Satuan yang digunakan untuk menilai ketepatan waktu adalah persen $(\%)$.

c. Service, penilaian service atau pelayanan adalah nilai yang dihasilkan dari pelayanan yang diberikan oleh subkontrak yaitu ketersediaan alat komunikasi, mudah dihubungi dan respon yang cepat jika terjadi masalah. Satuan yang digunakan untuk menilai kriteria service (pelayanan) adalah persen (\%).

d. Harga, penilaian harga yang diberikan oleh masing-masing calon subkontrak. Satuan untuk penilaian harga adalah rupiah.

Pada saat penelitian dilakukan, perusahaan sudah mempunyai bobot kepentingan terhadap masing-masing kriteria yang digunakan untuk penilaian yaitu kualitas (0.40), ketepatan waktu (0.30), service (0.15) dan harga (0.15). Pada pelaksanaannya kriteria yang digunakan hanya pada kriteria kualitas dan ketepatan waktu, sementara kriteria service dan harga tidak dihitung secara pasti.

Dukungan DSS pada proses pemilihan subkontrak untuk produksi sarung tangan tidak hanya mengusulkan alternatif (subkontrak terbaik), tetapi dapat mengusulkan bobot kepentingan pada setiap kriteria yang akan digunakan pada pengambilan keputusan. Kriteria utama untuk pemilihan subkontrak yang terbaik terdiri dari kualitas, ketepatan waktu, harga dan pelayanan dari subkontrak, tetapi tidak menutup kemungkingan beberapa kriteria lain dapat digunakan sebagai kriteria pengambilan keputusan, misalnya kapasitas dan jumlah karyawan. Gambaran keseluruhan proses pemilihan subkontrak dan dukungan DSS pada proses pemilihan subkontrak ditunjukkan pada gambar 1 . 


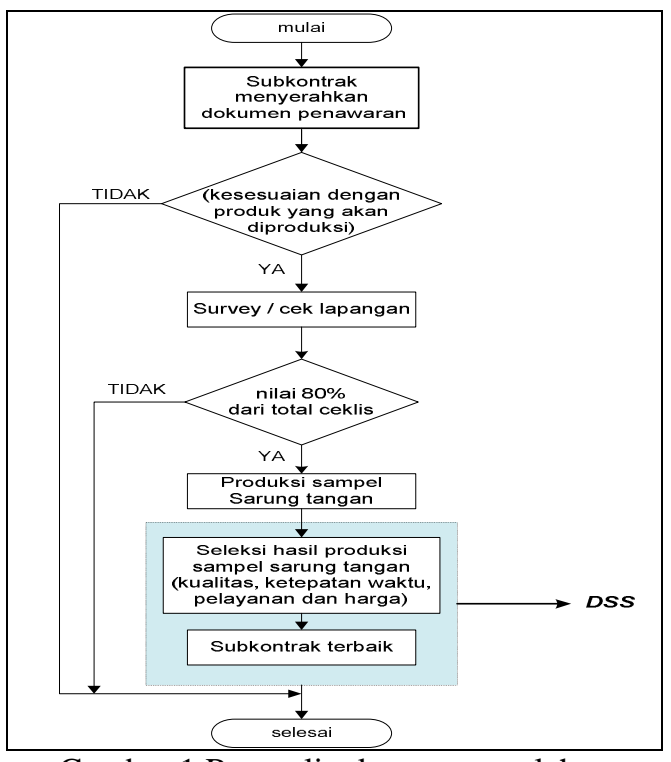

Gambar 1 Ruang lingkup permasalahan

\subsection{Metodologi Penyelesaian Masalah}

Berdasarkan proses pemilihan subkontrak (gambar 1) dan metode (entropy dan Topsis) yang digunakan untuk menyelesaikan permasalahan selanjutnya dibuat diagram alir penyelesaian masalah seperti pada gambar 2 .

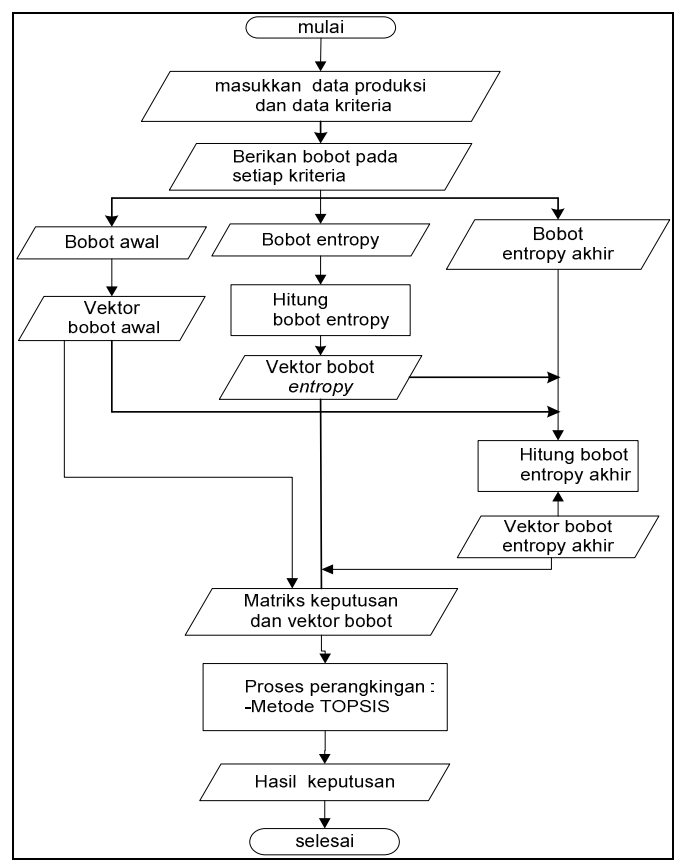

Gambar 2 Diagram alir penyelesaian masalah

\subsection{Komponen Sistem Pendukung Keputusan}

Salah satu alternatif dalam pemecahan masalah pemilihan subkontrak pada perusahaan bagi pembuat keputusan adalah dengan membangun sistem pendukung keputusan untuk memilh subkontrak yang terbaik. Sistem pendukung keputusan mampu mengevaluasi beberapa kriteria dalam penilaian melalui proses perhitungan, yang pada akhirnya dari alternatif tersebut akan memberikan keluaran pilihan subkontrak mana yang yang terbaik untuk memproduksi sarung tangan.

Komponen sistem pendukung keputusan pemilihan subkontrak dapat dilihat pada gambar 3 di bawah ini, yaitu basis data, basis model, subsistem manajemen basis data, subsistem basis model, subsistem dialog layar terminal (user interface).

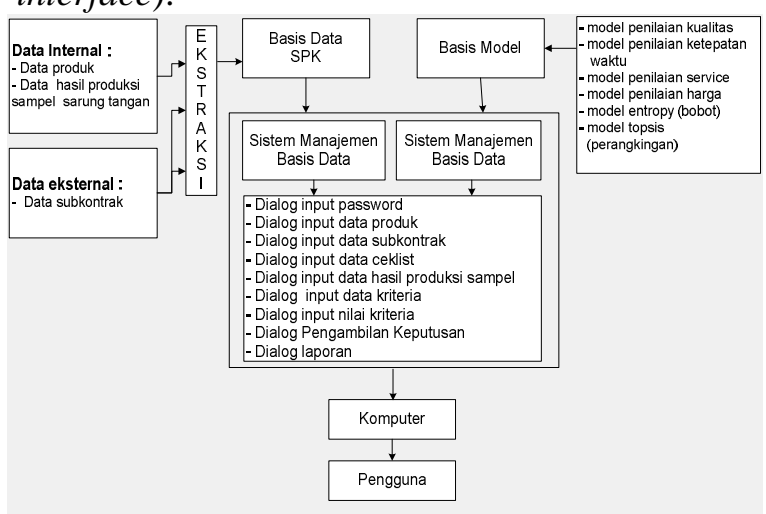

Gambar 3 Komponen sistem pendukung keputusan pemilihan subkontrak

\subsection{Perancangan Sistem}

Berdasarkan gambar 1, gambar 2 dan gambar 3 selanjutnya dilakukan perancangan sistem dengan menggunakan Entity Relational Diagram (ERD) untuk menggambarkan hubungan entitas yang ada pada sistem dan Data Flow Diagram (DFD) untuk menggambarkan proses aliran data[15]. DFD level 0 adalah gambaran umum dari sistem yaitu terdiri sistem dan lingkungan di luar sistem seperti ditunjukkan pada gambar 4.

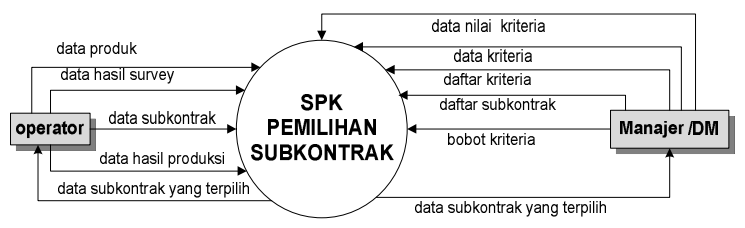

Gambar 4 DFD level 0

DFD level 0 terdiri dari sistem pendukung keputusan pemilihan subkontrak dan pengguna sistem. Pengguna (user) yang terlibat dalam sistem adalah operator dan pengambil keputusan. Operator, yaitu pengguna yang memberikan inputan berupa data produk, data subkontrak, data hasil ceklist dan data hasil produksi. Operator dapat melihat hasil keputusan yaitu informasi subkontrak yang terpilih. Pengambil keputusan (manajer), yaitu pengguna yang memberikan inputan berupa data kriteria, data nilai kriteria, menentukan bobot kepentingan dari masing-masing kriteria. Manajer dapat melakukan pengambilan keputusan dan melihat 
hasil keputusan yaitu informasi subkontrak yang terpilih.

\subsection{Implementasi}

Sistem dibangun dengan menggunakan bahasa pemrograman Borland Delphi 7.0 sebagai interaksi antarmuka pemakai (user interface), untuk program database-nya[16] menggunakan MySQL dan sistem bersifat stand alone. Hasil implementasi untuk dialog keputusan seperti pada gambar 5 .

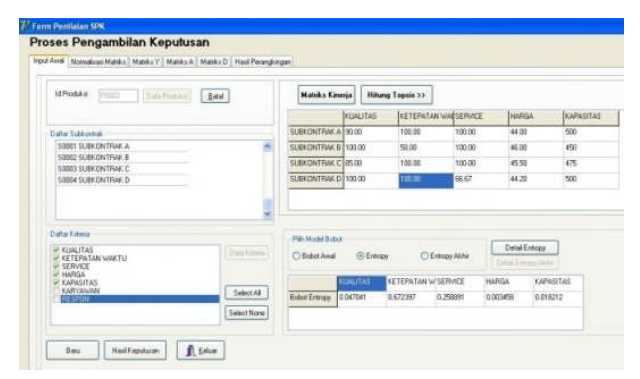

Gambar 5 Dialog pengambilan keputusan

\section{HASIl DAN PEMBAHASAN}

Pada sistem pendukung keputusan pemilihan subkontrak, kriteria pemilihan dapat ditambah sesuai keinginan dari pengguna. Jika pengguna ingin menambahkan kriteria baru, maka sebelum masuk pada form pengambilan keputusan, pengguna harus memasukkan nama kriteria pada form masukan data kriteria dan memasukkan nilai pada kriteria yang ditambahkan tersebut pada form masukan nilai. Jumlah kriteria pada saat pengambilan keputusan juga dapat ditambah atau dikurangi, sehingga pengambil keputusan dapat memilih kriteria sesuai dengan keinginan.

Penetapan bobot dalam sistem diberikan dengan 3 cara atau model yaitu model bobot awal, bobot entropy dan bobot entropy akhir. Pada hasil implementasi sistem, kriteria yang digunakan bersifat dinamis, sehingga pengambil keputusan dapat menambahkan kriteria baru misalnya (kapasitas) serta jumlah kriteria yang digunakan disesuaikan dengan keinginan dari pengambil keputusan.

Pengujian dilakukan dengan menggunakan data hasil produksi sampel sarung tangan. Hasil pengujian berdasarkan data tersebut, memberikan hasil bobot pada setiap kriteria berbeda antara bobot awal dan bobot entropy. Pada bobot awal, yang menjadi kriteria utama adalah kriteria kualitas dengan nilai bobot 0.40 , pada hasil bobot entropy yang menjadi kriteria utama adalah kriteria ketepatan waktu dengan nilai bobot 0.047914, sedangkan pada bobot entropy akhir yang menjadi kriteria utama atau kriteria yang sangat penting adalah kriteria ketepatan waktu dengan nilai bobot 0.776177 . Perbedaan tersebut dikarenakan pada metode entropy, data yang mempunyai range nilai yang besar dan mempunyai variasi nilai yang tinggi untuk tiap alternatif akan memperoleh bobot yang tinggi dan menjadi kriteria utama dalam pengambilan keputusan. Hasil perbandingan dari model bobot awal, bobot entropy dan bobot entropy akhir seperti ditunjukkan pada tabel 1 .

Tabel 1 Perbandingan hasil bobot

\begin{tabular}{|l|c|c|c|}
\hline \multirow{2}{*}{ Kriteria } & \multicolumn{3}{c|}{ Bobot } \\
\cline { 2 - 4 } & Awal & Entropy & $\begin{array}{c}\text { Entropy } \\
\text { Akhir }\end{array}$ \\
\hline Kualitas & 0.40 & 0.047914 & 0.072403 \\
\hline Ketepatan waktu & 0.30 & 0.684870 & 0.776177 \\
\hline Harga & 0.15 & 0.003522 & 0.001996 \\
\hline Service & 0.15 & 0.263694 & 0.149425 \\
\hline
\end{tabular}

Setelah menetapkan model bobot yang digunakan, selanjutnya dilakukan proses perangkingan dengan menggunakan metode TOPSIS untuk mendapatkan subkontrak yang terbaik berdasarkan kriteria yang digunakan.

Hasil perangkingan dengan menggunakan ketiga model bobot tersebut memberikan hasil dengan perbedaan pada nilai akhir. Hasil peringkat nomor 1 tidak terdapat perbedaan, perbedaan peringkat dari ketiga model penetapan bobot kriteria yang digunakan terdapat pada peringkat ke 3 dan ke 4. Hasil bobot pada masing-masing kriteria (tabel 1) untuk bobot awal yaitu (hasil bobot entropy merujuk pada tabel 1) memberikan hasil perangkingan seperti pada tabel 2 .

Tabel.2 Hasil perangkingan menggunakan bobot awal

\begin{tabular}{|c|c|}
\hline Nama subkontrak & Nilai akhir \\
\hline Subkontrak A & 0.805548 \\
\hline Subkontrak D & 0.767978 \\
\hline Subkontrak C & 0.731998 \\
\hline Subkontrak B & 0.334050 \\
\hline
\end{tabular}

Subkontrak yang mendapatkan nilai akhir tertinggi adalah Subkontrak A dan layak untuk tepilih. Sedangkan hasil perangkingan menggunakan bobot entropy (hasil bobot entropy merujuk pada tabel 1) memberikan hasil seperti pada tabel 3 .

Tabel 3 Hasil perangkingan menggunakan bobot entropy

\begin{tabular}{|c|c|}
\hline Nama subkontrak & Nilai akhir \\
\hline Subkontrak A & 0.987145 \\
\hline Subkontrak C & 0.980838 \\
\hline Subkontrak D & 0.800476 \\
\hline Subkontrak B & 0.200076 \\
\hline
\end{tabular}


Terdapat perbedaan rangking perolehan nilai akhir dengan hasil perangkingan menggunakan bobot awal (tabel 3), yaitu pada urutan rangking 2 dan 3. Pada hasil perangkingan dengan menggunakan bobot awal, rangking ke-2 adalah Subkontrak D dengan nilai akhir 0.767978, sedangkan pada hasil perangkingan dengan menggunakan bobot entropy, rangking ke-2 ditempati oleh Subkontrak C dengan nilai 0.980838. Rangking ke-1 tetap ditempati oleh Subkontrak A dengan nilai akhir 0.987145 dan posisi ke-4 ditempati oleh Subkontrak B dengan nilai akhir 0.200076, sehingga subkontrak yang layak untuk dipilih adalah Subkontrak A. Hasil perangkingan menggunakan bobot entropy akhir (hasil bobot entropy akhir merujuk pada tabel 1) memberikan hasil perangkingan seperti ditunjukkan pada tabel 4.

Tabel 4 Hasil perangkingan menggunakan bobot entropy akhir

\begin{tabular}{|c|c|}
\hline Nama subkontrak & Nilai akhir \\
\hline Subkontrak A & 0.982553 \\
\hline Subkontrak C & 0.974055 \\
\hline Subkontrak D & 0.889198 \\
\hline Subkontrak B & 0.113091 \\
\hline
\end{tabular}

Hasil perangkingan menggunakan bobot entropy akhir sama dengan hasil perangkingan menggunakan bobot entropy dalam hal urutan perolehan rangking, yang berbeda adalah pada perolehan nilai akhir dari masing-masing alternatif (subkontrak). Pada perangkingan menggunakan bobot entropy akhir, subkontrak terbaik adalah subkontrak A dengan nilai akhir 0.982553 sehingga layak untuk dipilih.

\section{KESIMPULAN}

Terdapat perbedaan pada bobot yang dihasillkan dengan menggunakan metode entropy dengan bobot awal karena pada bobot entropy data yang mempunyai range nilai yang besar dan mempunyai variasi nilai yang tinggi untuk tiap alternatif akan memperoleh bobot yang tinggi dan menjadi kriteria utama dalam pengambilan keputusan. Perbedaan hasil perangkingan dikarenakan perbedaan model bobot yang diberikan pada kriteria. Sistem pengambilan keputusan dapat menjadi alternatif bagi pihak perusahaan untuk memilih subkontrak yang akan memproduksi sarung tangan.

Sistem ini masih dapat dikembangkan dengan menggabungkan metode entropy dengan berbagai metode MADM yang lain untuk melihat perbandingan hasil yang diberikan dari masingmasing metode perangkingan.

\section{DAFTAR PUSTAKA}

[1] Ahyari, A., 1985, Manajemen Produksi, Perencanaan Sistem Produksi Buku I, Edisi keempat, BPFE, Yogyakarta.

[2] Soewito, 1992, Pengembangan Industri Kecil, Suara Merdeka, 12 Desember 1992. http://www. damandiri.or.id/file/arirahmathakimundipbab2a.pdf,diakses 10 Maret 2010

[3] Iwantono, S., 2004, Pengembangan Kemitraan Usaha Pola Sub Kontrak Berlandaskan Persaingan Sehat, Infokop Nomor 25 Tahun XX, 2004, http://www.smecda.com/deputi7/file_infokop/EDISI\%2025/p olasub-kontrak.pdf, diakses 11 Februari 2010.

[4] Turban, E., and Aronson, J.E., 2001, Decision Support Systems and Intelligent Systems. $6^{\text {th }}$ Edition, Prentice Hall Internatinal, New Jersey.

[5] Simon, J.L., 2000, Developing Decision Making Skill for Business, Armonk, NY.M.E dalam Turban, Efraim and J.E Aronson, 2001, Decision Support Systems and Intelligent Systems. $6^{\text {th }}$ Edition, Prentice Hall Internatinal, New Jersey.

[6] McLeod, Jr. R., dan George, S., 2001, Sistem Informasi Manajemen, Edisi Kedelapan, Indeks, Jakarta.

[7] Mauidzoh, U dan Zabidi, Y., 2007, Perancangan Sistem Penilaian dan Seleksi Supplier Menggunakan Multi Kriteria, Jurnal Ilmiah Teknik Industri, volume 5, no. 3, hal 113 - 122.

[8] Wang, Y., Kao, C.S., 2007, Applying Fuzzy Multiple Criteria Decision Making Method to Select the Distribution Center, Fourth International Conference on Fuzzy Systems and Knowledge Discovery, IEEE Computer Society. http://ieeexplore.ieee.org/xpl/freeabs_al.jps?arnumber=44064 33, diakses 15 Maret 2010.

[9] Triyanti, V., dan Gadis, M.T., 2008, Pemilihan Supllier untuk Industri Makanan Menggunakan Promethee, Journal of Logistics and Supply Chain Management, volume 1, No. 2, hal. 83-92, http:/jurnal.pdii.lipi.go.id/admin/jurnal/1208.839.pdf,diakses 13 Januari 2011.

[10] Xie, P., 2008, Development Ranking in Real Estate Strategy Management in China Based on TOPSIS Method, ISECS International Colloquium on Computing, Communication, Control, and Management, volume 3, pp.254-258. http://www.computer.org/portal/web/csdl/doi/10.1109/CCC M.2008.376, diakses 10 April 2010.

[11] Salehi, M., Moghaddam, R.T., 2008, Project Selection by Using a Fuzzy TOPSIS Technique, Department of Industrial Engineering at University of Tehran in Iran. http://www/waset.org/journals /waset/v40/v40-17.pdf, diakses 10 Maret 2010.

[12] Pieter, M.S.S., 2009, Pemanfataan Analytical Hierarchy Process (AHP) sebagai Model Sistem Pendukung Keputusan Penentuan Penerima Beasiswa pada Universitas Sains dan Teknologi Jayapura, Tesis, Jurusan Ilmu Komputer dan Elektronika FMIPA UGM, Yogyakarta.

[13] Kusumadewi, S., Hartati, S., Harjoko, A., dan Wardoyo, R., 2006, Fuzzy Multi-Attribute Decision Making (FUZZY $M A D M)$, Graha Ilmu, Yogyakarta.

[14] Bashor, M., 2004, Profil PT. Adi Satria Abadi pada Divisi Sarung Tangan, PT. Adi Satria Abadi, Yogyakarta.

[15] Pressman, R.S., 1992, Software Engineering, Third Edition, McGraw-Hill Inc., New York.

[16] Silberchat, Kohr dan Sudarsan., 2000, Database System Concept, $4^{\text {th }}$ Edition, McGraw-Hill Inc, New York 